\title{
Movement patterns and home range size of tigerfish (Hydrocynus vittatus) in the Incomati River system, South Africa
}

\begin{tabular}{|c|c|}
\hline \multicolumn{2}{|c|}{$\begin{array}{l}\text { Authors: } \\
\text { Francois Roux } x^{1,2} \\
\text { Gert Steyn }{ }^{1} \text { (D) } \\
\text { Clinton Hay } \\
\text { Ina Wagenaar }{ }^{1} \text { (D) }\end{array}$} \\
\hline \multicolumn{2}{|c|}{$\begin{array}{l}\text { Affiliations: } \\
{ }^{1} \text { Department of Zoology, } \\
\text { University of Johannesburg, } \\
\text { South Africa }\end{array}$} \\
\hline \multicolumn{2}{|c|}{$\begin{array}{l}{ }^{2} \text { Scientific Services, } \\
\text { Mpumalanga Tourism and } \\
\text { Parks Agency, South Africa }\end{array}$} \\
\hline \multicolumn{2}{|c|}{$\begin{array}{l}{ }^{3} \text { Department of Biological } \\
\text { Sciences, University of } \\
\text { Namibia, Namibia }\end{array}$} \\
\hline \multicolumn{2}{|c|}{$\begin{array}{l}\text { Corresponding author: } \\
\text { Ina Wagenaar, } \\
\text { inaw@uj.ac.za }\end{array}$} \\
\hline \multicolumn{2}{|c|}{$\begin{array}{l}\text { Dates: } \\
\text { Received: } 21 \text { Apr. } 2016 \\
\text { Accepted: } 05 \text { Apr. } 2018 \\
\text { Published: } 27 \text { June } 2018\end{array}$} \\
\hline \multicolumn{2}{|c|}{$\begin{array}{l}\text { How to cite this article: } \\
\text { Roux, F., Steyn, G., Hay, C. } \\
\text { \& Wagenaar, I., 2018, } \\
\text { 'Movement patterns and } \\
\text { home range size of tigerfish } \\
\text { (Hydrocynus vittatus) in the } \\
\text { Incomati River system, South } \\
\text { Africa', Koedoe 60(1), a1397. } \\
\text { https://doi.org/10.4102/ } \\
\text { koedoe.v60i1.1397 }\end{array}$} \\
\hline \multicolumn{2}{|c|}{$\begin{array}{l}\text { Copyright: } \\
\text { C 2018. The Authors } \\
\text { Licensee: AOSIS. This } \\
\text { is licensed under the } \\
\text { Creative Commons } \\
\text { Attribution License. }\end{array}$} \\
\hline \multicolumn{2}{|l|}{ Read online: } \\
\hline 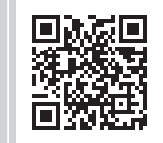 & $\begin{array}{l}\text { Scan this QR } \\
\text { code with your } \\
\text { smart phone or } \\
\text { mobile device } \\
\text { to read online. }\end{array}$ \\
\hline
\end{tabular}

Historical data suggested that the tigerfish (Hydrocynus vittatus) of the Incomati River migrates upstream and downstream as part of their life history. It has been suggested that this movement was a prerequisite for successful spawning in inundated floodplains in Mozambique. Recent advances in aquatic radio telemetry provided a reliable mechanism to monitor fish movement and increase knowledge of the ecology of tigerfish. From 04 January 2003 to 22 December 2003, 41 tigerfish in the Incomati River system were fitted with radio transmitters to record movement patterns and estimate home range size. On average, each fish was tracked 72 times, and the total number of fixes was 2971 over the study period, including 1322 summer fixes and 1649 winter fixes. The mean longest distance travelled by tigerfish was $730 \mathrm{~m}$ (range $=75 \mathrm{~m}$ to $3200 \mathrm{~m}$ ). The home range size varied between individual fish, but on average fish stayed within a defined home range of $48846 \mathrm{~m}^{2}$. Tigerfish showed high site fidelity to specific habitats within specific activity zones and movement occurred primarily within these defined zones. Differences in movement pattern, longest distance travelled and home range size could not be attributed to the sex or size of the fish. No large-scale movement patterns associated with specific life history activity were observed; thus, previous reports of large-scale downstream migrations and spawning migrations appear to be invalid. The presence of weirs in the study area impedes free fish movement as these weirs create migration obstructions.

Conservation implications: River regulation such as damming, water abstraction, obstructive barriers and channel modification may have a detrimental impact on the survival strategy of this species. Implementation of these results in a management policy will provide a reliable basis for species specific requirements such as upstream reservoir release management; minimum flow volumes required for downstream ecosystem maintenance and management and planning of structures obstructing natural flow.

\section{Introduction}

The freshwater fish genus Hydrocynus is represented by six species, all endemic to Africa. They are pikelike predators, commonly termed 'tigerfishes' for their prominent dentition and dark lateral stripes (Gery 1977). In southern Africa, one of these species, Hydrocynus vittatus (commonly known as tigerfish), occurs in the Zambezi and Okavango Rivers and in the lowveld reaches of coastal systems (Skelton 2001). The southern African tigerfish (H. vittatus) has a limited distribution in South Africa, where it is restricted to the lowveld reaches of the Limpopo River system, mainly within the Kruger National Park (KNP), and further south in the lower reaches of the Usutho and Phongolo Rivers (Gaigher 1967).

The Incomati River system (South Africa) is a marginal area in the distribution range of tigerfish where they occur in relatively low abundance. Being essentially a lowveld species in South Africa, it is intolerant to cold water and migrates downstream to lower lying reaches of these rivers during winter where water temperatures are higher and more stable (Pienaar 1978; Steyn et al. 1996; Van Loggerenberg 1983; Skelton 2001). Mortalities caused by a sudden drop in temperature $\left(<16.0^{\circ} \mathrm{C}\right)$ related to cold water in the Incomati River were reported on several occasions (Deacon 1991; Gagiano 1997; personal observation by authors; Van Loggerenberg 1983). Gagiano (1997) reported mortalities in the Piet Grobler Dam in the KNP at a temperature of $14.5^{\circ} \mathrm{C}$ during the winter period.

The habitat and environmental conditions in the Incomati River system differ considerably from the favourable conditions present in the larger northern tropical river systems such as the Zambezi River. Tigerfish are inhabitants of open, well-oxygenated waters such as found in the larger rivers and lakes (Pienaar 1978). In contrast to the larger rivers and lakes in the north of South Africa, the rivers of the KNP are relatively small, highly regulated because of anthropogenic impacts and 
subject to extreme seasonal variations (Du Preez \& Steyn 1992; Gertenbach 1991). Variation and flow volumes, especially in the presence of instream damming structures such as weirs, can severely impact the ability of fish species to migrate in accordance with their life history requirement (Baras \& Lucas 2002). Furthermore, all the major rivers of the KNP are subjected to high silt loads which can severely reduce dissolved oxygen concentrations of the water and may be lethal to fish (Buermann et al. 1995). There has been a long history of fish mortalities in the KNP caused by large amounts of suspended particles present in the water (KNP annual reports 1946-1992). The negative impact of increased silt loads on the aquatic macro-invertebrate diversity in the major rivers of the KNP was reported by Moore and Chutter (1988). Sub-lethal effects of suspended solids on fish are varied and include negative impacts on reproduction, egg survival, growth, oxygen consumption, haematology, feeding and social behaviour (Crouse, Callahan \& Malaug 1981; Wilber 1983). Indirect effects include reduced food availability, clogging of gillrakes and filaments, reduced growth rate, reduced resistance to disease and disturbances of natural movements and migrations of fish (Albaster \& Lloyd 1980; Bruton 1985).

Tigerfish has a prominent ecological status as top predator, sharing the same trophic level as crocodiles in the KNP riverine ecosystems. Their limited presence in the KNP and their vulnerability to impacts described above served as motivation for several studies since the work of Gaigher (1967).

In South Africa, research on tigerfish concentrated on ecological aspects (Gaigher 1970, 1973; 1975; Gagiano 1997; Van Loggerenberg 1983), reproduction (Steyn 1993; Steyn \& Van Vuren, 1992; Steyn et al. 1996), tooth replacement (Gagiano, Steyn \& Du Preez 1996), age estimation and maturity (Gerber et al. 2009) and genetics (Kotze et al. 1998). Recent advances in aquatic radio telemetry provided a reliable means to acquire further information on the behaviour ecology of fish species and to improve our knowledge on tigerfish.

Despite several comprehensive studies as mentioned above, conservationists and river managers were still left with key questions on the (1) migrational requirements, (2) movement patterns and (3) ability to overcome obstructions in order to maintain functionality of a viable tigerfish population in the Incomati River system. The objective of this study was to use biotelemetry to answer these key questions.

\section{Material and methods Description of the study area}

The Incomati River drains parts of Mpumalanga, Swaziland and Mozambique between the Limpopo River system in the north and the Phongolo River system in the south. It is economically one of the most important river basins in South Africa, and it consists of three adjacent sub-basins: the Komati, Crocodile and Sabie (Darwall et al. 2009). The main river descends from the highland plateau in Mpumalanga and Swaziland and flows through the coastal plains of Mozambique to the Indian Ocean just north of Maputo at
Villa Laisa. The total basin area is about $46800 \mathrm{~km}^{2}$ of which $63 \%$ is in South Africa, 5\% in Swaziland and 32\% in Mozambique. The average discharge of the Incomati River basin at the estuary is about $100 \mathrm{~m}^{3} / \mathrm{s}$ to $200 \mathrm{~m}^{3} / \mathrm{s}$, corresponding to about 3600 million $\mathrm{m}^{3}$ per year, to which South Africa contributes 82\%, Swaziland about 13\% and Mozambique about 4\% (Darwall et al. 2009).

The study area includes two rivers, namely the Crocodile River and the Komati River, which join to form the Incomati River below the border town of Komatipoort. The Crocodile River flows along the boundary of the KNP, and at the confluence, the border extends across the river to also include the lower reach of the Komati River (Figures 1 and 2). Below the confluence, the Incomati River can be described as a meandering river, incised into a wide sandy river bed, and in some sections, it flows through multiple bedrock channels. The river varies between $40 \mathrm{~m}$ and $50 \mathrm{~m}$ wide, with mostly large sandy pools and occasional rapids and a few riffles (Roux et al. 1990). Collection and tagging were done upstream and downstream of the confluence between KNP and Tenbosch weirs and the low-water bridge in the Komati River. The choice of the collection and tagging area was motivated by the relative abundance of tigerfish in this river reach. The ability of tigerfish to overcome obstructions and their various home ranges later defined the extent of the study area. Historically, tigerfish distribution data would indicate that tigerfish occur up to an altitude of $300 \mathrm{~m}$ in the Incomati River system. Gaigher (1967) previously collected tigerfish in the Crocodile River gauge close to the town of Nelspruit and in the Komati River close to the town of Tonga on the border between South Africa and Swaziland. Consequently, the experimental design made provision for long-distance tracking in relation to historical distribution in the Incomati River system.

\section{Collection and handling of the species}

Collection and handling of fish were performed in such a manner as to minimise physical and physiological stress to the specimens (Spedicato, Lembo \& Marmulla 2005). Tigerfish were caught using two techniques: rod and reel with artificial lures and fly-fishing, both using barbless hooks to reduce injury to fish and to facilitate quick release, thereby reducing lactic acid stress and ensuring survival after handling and release (Gerber et al. 2017).

\section{Tagging of fish}

In total, 41 sexually mature tigerfish were tagged with radio transmitters (Advanced Telemetric Systems Inc. ATS, USA, $142 \mathrm{MHz}-144 \mathrm{MHz}$ ) in 2003. As the sexing of H. vittatus is relatively difficult based on external characteristics, males were only positively identified if they were ripe and running and producing semen. Large females in or close to the spawning season were easily sexed as they displayed characteristic body size, form and weight (Gaigher 1967; Gagiano 1997; G.J. Steyn pers. comm., 2003). The standard length (SL) was measured (mm), and mass ( $\mathrm{g}$ ) of each specimen collected was determined using a measuring tape and a BogaGrip (scale). 


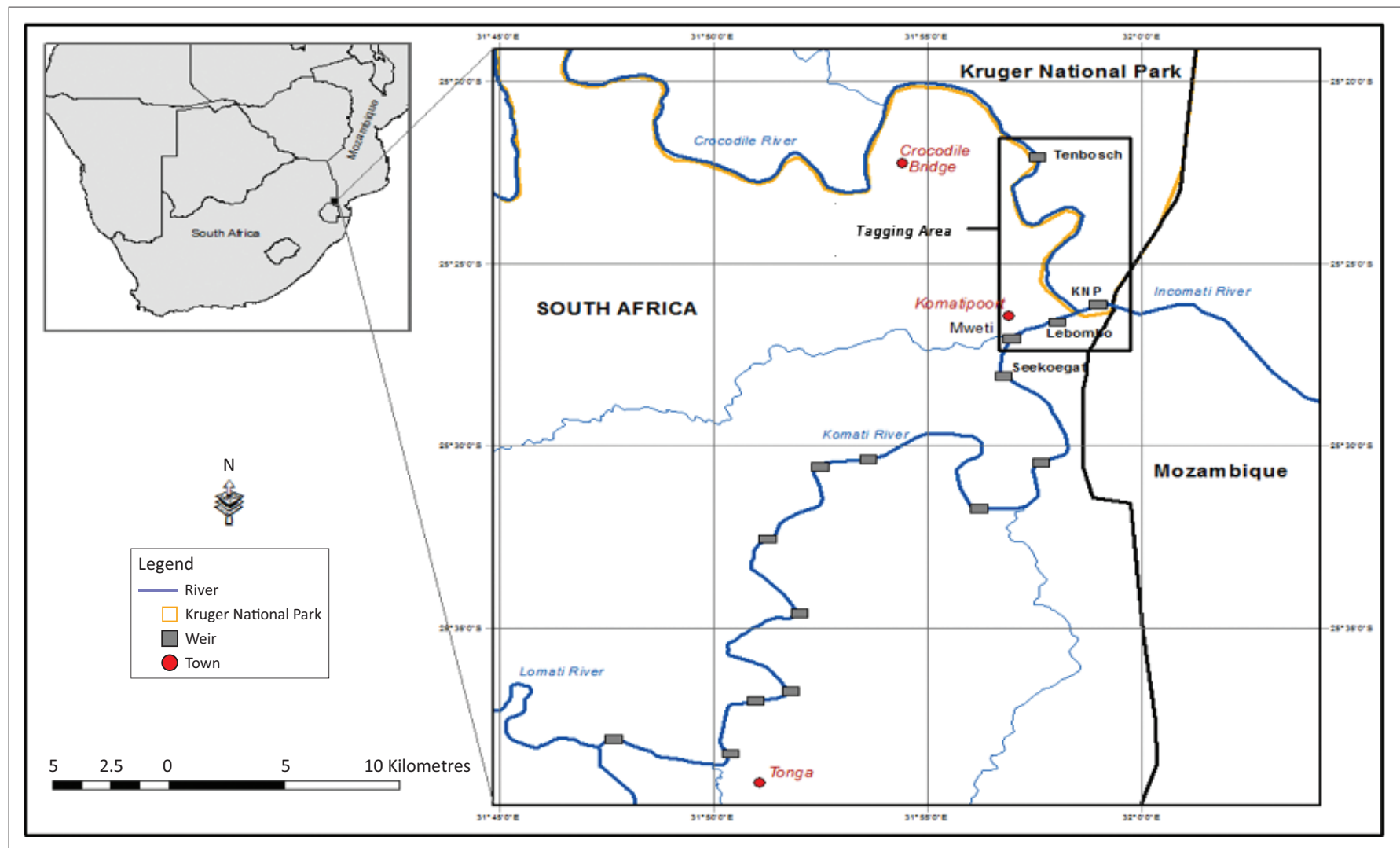

FIGURE 1: Map indicating the location of the study area in the Mpumalanga Province of South Africa, in close proximity to Mozambique. The applicable rivers are illustrated and marked with the numerous weirs.

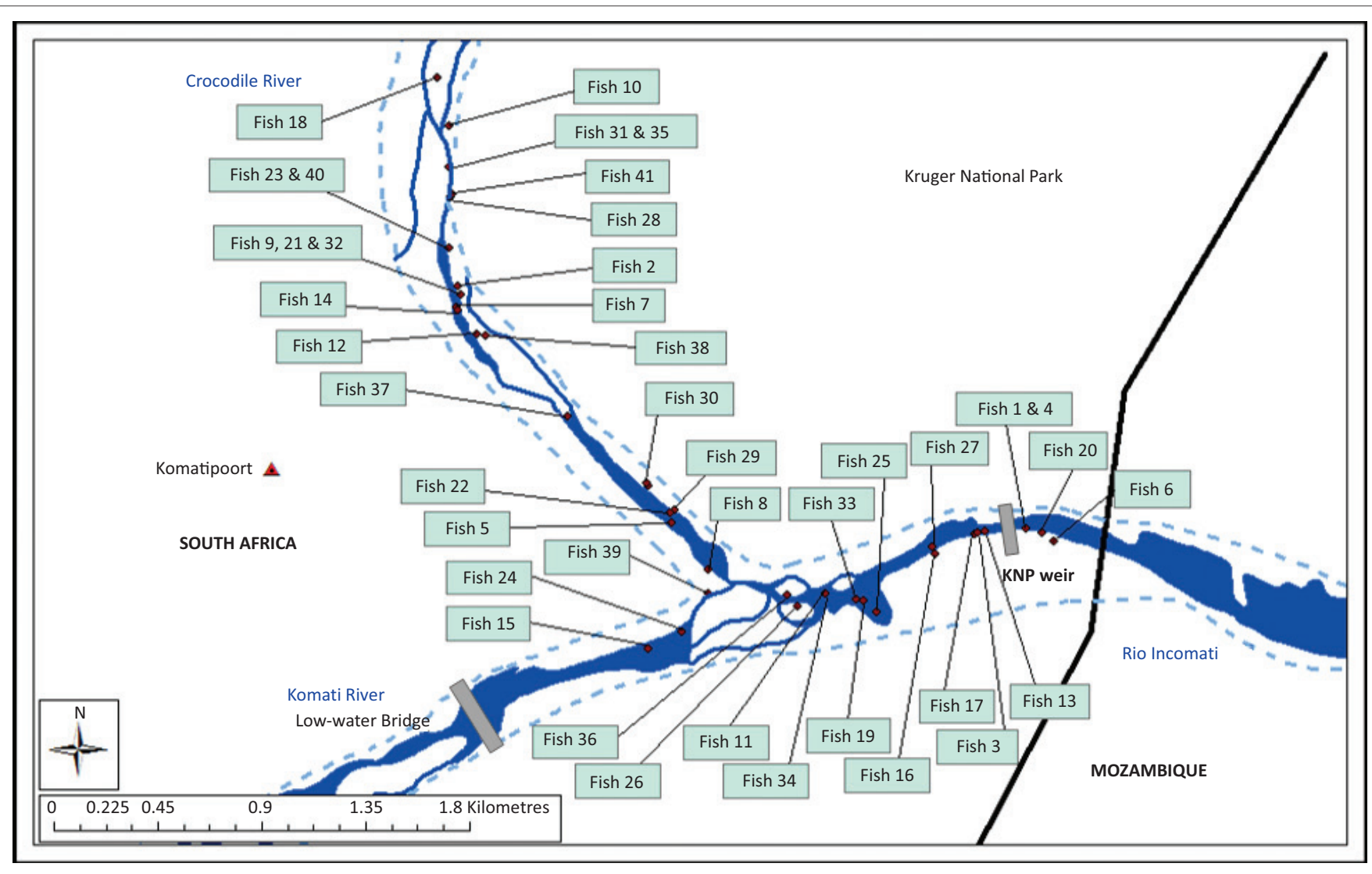

FIGURE 2: Map of the study area indicating tagging sites of all 41 radio-tagged fish. 
Following capture, fish were anaesthetised with 2-phenoxyethanol $(0.3 \mathrm{~mL} / \mathrm{L})$, minimising hyperactivity and stress. The radio transmitters were selected from ATS models F2040, F2130 and F2010 with trailing whip antennae and were externally attached to fish with two strands of orthopaedic wire $(0.65 \mathrm{~mm}$ diameter) below the dorsal fin following Thorstad, Økland and Heggeberget (2001). To facilitate rapid healing of the needle wounds, the tagged fish were placed in a terramycin bath $(25 \mathrm{mg} / \mathrm{L}$ water $)$ for $10 \mathrm{~min}$ prior to release. The deployment of the small F2040 transmitters made it possible to tag smaller fish because of the relatively low weight of the transmitter, but remaining within the $2 \%$ rule (Brown et al. 1999; Peake \& McKinley 1997).
All radio-tagged fish were released at their respective sampling points, and staggered deployment over several months allowed for continuous data retrieval over a full year period, consequently covering all seasons (Table 1; Figure 2). Staggered deployment was necessary because of the limited lifespan of the transmitters.

\section{Fish tracking procedures}

Fish were tracked using a Challenger R2100 receiver and a four-element Yagi antenna (ATS Inc.) over a 12-month period (04 January to 22 December 2003) on average every second day, covering both summer and winter periods. Care was taken to minimise behavioural side-effects by keeping a

TABLE 1: Individual fish collection, release and radio-tagging data (home range and longest distances).

\begin{tabular}{|c|c|c|c|c|c|c|c|c|c|}
\hline Fish number & Tagging date & GPS coordinates & $\begin{array}{l}\text { Length }(\mathrm{cm}) \\
\text { (SL) }\end{array}$ & Weight (g) & Sex & $\begin{array}{c}\text { Total number } \\
\text { of fixes }(n)\end{array}$ & Period (2003) & Home range & $\begin{array}{c}\text { Longest distance } \\
\text { travelled }\end{array}$ \\
\hline 1 & 10 December 2002 & $\begin{array}{c}\text { S25 } 26.172 \\
\text { E031 } 59.227\end{array}$ & 58 & 2720 & $\mathrm{~F}$ & 161 & January-October & $36710.77 \mathrm{~m}^{2}$ & $677.6 \mathrm{~m}$ \\
\hline 2 & 07 January 2003 & $\begin{array}{c}\text { S25 } 26.032 \\
\text { E031 } 58.275\end{array}$ & 73 & 3630 & $\mathrm{~F}$ & 72 & January-May & $21182.5 \mathrm{~m}^{2}$ & $840.4 \mathrm{~m}$ \\
\hline 3 & 13 November 2002 & $\begin{array}{c}\text { S25 } 26.141 \\
\text { E031 } 59.164\end{array}$ & 68 & 2720 & $\mathrm{~F}$ & 74 & January-February & $4960.1 \mathrm{~m}^{2}$ & $294.6 \mathrm{~m}$ \\
\hline 4 & 24 January 2003 & $\begin{array}{c}\text { S25 } 26.151 \\
\text { E031 } 59.051\end{array}$ & 57 & 1810 & $\mathrm{~F}$ & 56 & January-June & $129984.3 \mathrm{~m}^{2}$ & $1700 \mathrm{~m}$ \\
\hline 5 & 14 January 2003 & $\begin{array}{c}\text { S25 } 26.126 \\
\text { E031 } 58.336\end{array}$ & 58 & 1810 & $\mathrm{~F}$ & 92 & January-August & $9499.8 \mathrm{~m}^{2}$ & $465.4 \mathrm{~m}$ \\
\hline 6 & 21 January 2003 & $\begin{array}{c}\text { S25 26.186 } \\
\text { E031 } 58.945\end{array}$ & 61 & 2040 & $\mathrm{~F}$ & 48 & January-June & $19546.7 \mathrm{~m}^{2}$ & $718 \mathrm{~m}$ \\
\hline 7 & 17 December 2002 & $\begin{array}{c}\text { S25 } 25.606 \\
\text { E031 } 57.833\end{array}$ & 72 & 4540 & $\mathrm{~F}$ & 47 & January-September & $147278 \mathrm{~m}^{2}$ & $1300 \mathrm{~m}$ \\
\hline 8 & 12 February 2003 & $\begin{array}{c}\text { S25 } 26.301 \\
\text { E031 } 58.604\end{array}$ & 64 & 2270 & $\mathrm{~F}$ & 157 & March-December & $31471.3 \mathrm{~m}^{2}$ & $442.9 \mathrm{~m}$ \\
\hline 9 & 06 January 2003 & $\begin{array}{c}\text { S25 } 25.464 \\
\text { E031 } 57.816\end{array}$ & 64 & 2720 & $\mathrm{~F}$ & 58 & January-July & $9304 \mathrm{~m}^{2}$ & $447.8 \mathrm{~m}$ \\
\hline 10 & 07 November 2003 & $\begin{array}{c}\text { S25 } 25.200 \\
\text { E031 } 58.430\end{array}$ & 68 & 2500 & $\mathrm{~F}$ & 8 & November only & $56.4 \mathrm{~m}^{2}$ & $18.3 \mathrm{~m}$ \\
\hline 11 & 17 December 2002 & $\begin{array}{c}\text { S25 } 25.270 \\
\text { E031 } 57.813\end{array}$ & 63 & 2040 & $\mathrm{~F}$ & 6 & December only & $32023.7 \mathrm{~m}^{2}$ & $292.7 \mathrm{~m}$ \\
\hline 12 & 28 January 2003 & $\begin{array}{c}\text { S25 } 26.037 \\
\text { E031 } 58.279\end{array}$ & 65 & 2040 & $\mathrm{~F}$ & 103 & February-July & $9024.2 \mathrm{~m}^{2}$ & $1800 \mathrm{~m}$ \\
\hline 13 & 17 December 2003 & $\begin{array}{c}\text { S25 25.339 } \\
\text { E031 } 57.819\end{array}$ & 59 & 2040 & M & 7 & December only & $74223.5 \mathrm{~m}^{2}$ & $599.7 \mathrm{~m}$ \\
\hline 14 & 04 February 2003 & $\begin{array}{c}\text { S25 } 26.300 \\
\text { E031 } 58.421\end{array}$ & 74 & 3630 & $\mathrm{~F}$ & 107 & February-August & $106367 \mathrm{~m}^{2}$ & $946.1 \mathrm{~m}$ \\
\hline 15 & 04 March 2003 & $\begin{array}{c}\text { S25 } 26.431 \\
\text { E031 58.279 }\end{array}$ & 63 & 2600 & $\mathrm{~F}$ & 32 & March-August & $195532.4 \mathrm{~m}^{2}$ & $902.8 \mathrm{~m}$ \\
\hline 16 & 16 January 2003 & $\begin{array}{c}\text { S25 } 26.150 \\
\text { E031 } 59.201\end{array}$ & 68 & 3180 & $\mathrm{~F}$ & 45 & January-May & $75579.3 \mathrm{~m}^{2}$ & $988.8 \mathrm{~m}$ \\
\hline 17 & 16 April 2003 & $\begin{array}{c}\text { S25 } 26.154 \\
\text { E031 } 59.044\end{array}$ & 62 & 2500 & $\mathrm{~F}$ & 122 & May-November & $236496 \mathrm{~m}^{2}$ & $915.8 \mathrm{~m}$ \\
\hline 18 & 17 December 2002 & $\begin{array}{c}\text { S25 } 25.606 \\
\text { E031 } 57.833\end{array}$ & 58 & 1810 & $\mathrm{M}$ & 24 & January-August & $135982.6 \mathrm{~m}^{2}$ & $1800 \mathrm{~m}$ \\
\hline 19 & 17 July 2003 & $\begin{array}{c}\text { S25 } 26.328 \\
\text { E031 58.628 }\end{array}$ & 65 & 2270 & $\mathrm{~F}$ & 71 & July-December & $68401.7 \mathrm{~m}^{2}$ & $743.8 \mathrm{~m}$ \\
\hline 20 & 13 November 2002 & $\begin{array}{c}\text { S25 } 26.141 \\
\text { E031 } 59.164\end{array}$ & 63 & 2270 & $\mathrm{~F}$ & 45 & January-April & $23921.3 \mathrm{~m}^{2}$ & $517.7 \mathrm{~m}$ \\
\hline 21 & 01 June 2003 & $\begin{array}{c}\text { S25 } 25.671 \\
\text { E031 } 57.881\end{array}$ & 70 & 2720 & $\mathrm{~F}$ & 129 & June-December & $18250.2 \mathrm{~m}^{2}$ & $612.1 \mathrm{~m}$ \\
\hline 22 & 14 January 2003 & $\begin{array}{c}\text { S25 } 26.242 \\
\text { E031 } 58.420\end{array}$ & 69 & 3550 & $\mathrm{~F}$ & 162 & January-October & $46693.6 \mathrm{~m}^{2}$ & 908.7 m \\
\hline 23 & 25 July 2003 & $\begin{array}{c}\text { S25 } 25.555 \\
\text { E031 } 57.836\end{array}$ & 68 & 2950 & $\mathrm{~F}$ & 86 & July-December & $194210 \mathrm{~m}^{2}$ & $3200 \mathrm{~m}$ \\
\hline 24 & 26 July 2003 & $\begin{array}{c}\text { S25 } 25.675 \\
\text { E031 } 57.900\end{array}$ & 62 & 2270 & $\mathrm{~F}$ & 30 & August-December & $8056.6 \mathrm{~m}^{2}$ & $208.4 \mathrm{~m}$ \\
\hline 25 & 23 January 2003 & $\begin{array}{c}\text { S25 } 26.095 \\
\text { E031 } 58.340\end{array}$ & 76 & 4990 & $\mathrm{~F}$ & 42 & January-April & $10991.1 \mathrm{~m}^{2}$ & $291.6 \mathrm{~m}$ \\
\hline 26 & 25 July 2003 & $\begin{array}{c}\text { S25 } 25.613 \\
\text { E031 } 57.835\end{array}$ & 61 & 2270 & $\mathrm{~F}$ & 58 & August-December & $9373.4 \mathrm{~m}^{2}$ & $274.4 \mathrm{~m}$ \\
\hline 27 & 16 January 2003 & $\begin{array}{c}\text { S25 } 26.202 \\
\text { E031 } 58.949\end{array}$ & 54 & 1360 & M & 123 & January-July & $7746.4 \mathrm{~m}^{2}$ & $420.6 \mathrm{~m}$ \\
\hline
\end{tabular}


TABLE 1 (Continues...): Individual fish collection, release and radio-tagging data (home range and longest distances).

\begin{tabular}{|c|c|c|c|c|c|c|c|c|c|}
\hline Fish number & Tagging date & GPS coordinates & $\begin{array}{l}\text { Length (cm) } \\
(\mathrm{SL})\end{array}$ & Weight (g) & Sex & $\begin{array}{c}\text { Total number } \\
\text { of fixes }(n)\end{array}$ & Period (2003) & Home range & $\begin{array}{l}\text { Longest distance } \\
\text { travelled }\end{array}$ \\
\hline 28 & 28 August 2003 & $\begin{array}{c}\text { S25 } 26.311 \\
\text { E031 58.765 }\end{array}$ & 62 & 2040 & $\mathrm{~F}$ & 60 & August-December & $331.6 \mathrm{~m}^{2}$ & $74.5 \mathrm{~m}$ \\
\hline 29 & 27 August 2003 & $\begin{array}{c}\text { S25 } 26.344 \\
\text { E031 58.814 }\end{array}$ & 47 & 910 & M & 70 & August-December & $86965 \mathrm{~m}^{2}$ & $1400 \mathrm{~m}$ \\
\hline 30 & 15 January 2003 & $\begin{array}{c}\text { S25 } 26.103 \\
\text { E031 } 58.332\end{array}$ & 57 & 1810 & M & 95 & January-July & $88288.2 \mathrm{~m}^{2}$ & $1400 \mathrm{~m}$ \\
\hline 31 & 05 August 2003 & $\begin{array}{c}\text { S25 } 25.270 \\
\text { E031 } 57.813\end{array}$ & 60 & 1810 & M & 77 & August-December & $13181.9 \mathrm{~m}^{2}$ & $744.6 \mathrm{~m}$ \\
\hline 32 & 02 May 2003 & $\begin{array}{c}\text { S25 } 25.577 \\
\text { E031 } 57.842\end{array}$ & 58 & 1580 & M & 115 & May-December & $15019.5 \mathrm{~m}^{2}$ & $582.9 \mathrm{~m}$ \\
\hline 33 & 27 August 2003 & $\begin{array}{c}\text { S25 } 26.317 \\
\text { E031 } 58.783\end{array}$ & 64 & 2800 & $\mathrm{~F}$ & 71 & August-December & $30298.8 \mathrm{~m}^{2}$ & $280 \mathrm{~m}$ \\
\hline 34 & 20 March 2003 & $\begin{array}{c}\text { S25 } 26.298 \\
\text { E031 58.694 }\end{array}$ & 71 & 3580 & $\mathrm{~F}$ & 58 & March-June & $27367.1 \mathrm{~m}^{2}$ & $488.8 \mathrm{~m}$ \\
\hline 35 & 03 November 2003 & $\begin{array}{c}\text { S25 } 25.577 \\
\text { E03157.842 }\end{array}$ & 61 & 1810 & $\mathrm{~F}$ & 26 & November-December & $13984.1 \mathrm{~m}^{2}$ & $177.6 \mathrm{~m}$ \\
\hline 36 & 24 March 2003 & $\begin{array}{c}\text { S25 } 26.300 \\
\text { E031 } 58.694\end{array}$ & 52 & 1360 & M & 53 & March-June & $3128.5 \mathrm{~m}^{2}$ & $232.1 \mathrm{~m}$ \\
\hline 37 & 12 February 2002 & $\begin{array}{c}\text { S25 } 26.149 \\
\text { E03159.067 }\end{array}$ & 54 & 1360 & $M$ & 60 & January-May & $10075.2 \mathrm{~m}^{2}$ & $206.2 \mathrm{~m}$ \\
\hline 38 & 11 December 2002 & $\begin{array}{c}\text { S25 } 25.872 \\
\text { E031 } 58.092\end{array}$ & 57 & 1810 & M & 88 & January-May & $2132.9 \mathrm{~m}^{2}$ & $227.6 \mathrm{~m}$ \\
\hline 39 & 07 November 2003 & $\begin{array}{c}\text { S25 } 26.390 \\
\text { E031 } 58.360\end{array}$ & 68 & 3420 & $\mathrm{~F}$ & 20 & November only & $2597.3 \mathrm{~m}^{2}$ & $99.7 \mathrm{~m}$ \\
\hline 40 & 05 February 2003 & $\begin{array}{c}\text { S25 } 25.577 \\
\text { E031 } 57.842\end{array}$ & 65 & 2270 & $\mathrm{~F}$ & 116 & May-October & $4889.8 \mathrm{~m}^{2}$ & $246.6 \mathrm{~m}$ \\
\hline 41 & 05 August 2003 & $\begin{array}{c}\text { S25 } 25.334 \\
\text { E031 } 57.822\end{array}$ & 53 & 1810 & M & 96 & August-December & $1338.8 \mathrm{~m}^{2}$ & $148.9 \mathrm{~m}$ \\
\hline
\end{tabular}

Fish struck through not used for useful statistics because of number of fixes $<10$.

GPS, Global Positioning System; SL, standard length; M, male; F, female.

reasonable distance from tagged fish (Hocutt, Seibold \& Jesien 1994). Tracking was done on foot from the banks of the river by using the homing-in technique (Jick 1979). If there was any uncertainty regarding the position of the fish, the triangulation method was then applied (Jick 1979). In instances where fish were lost, aerial surveys were conducted using a micro-light aircraft to relocate a specific fish. For all tracking surveys, location was determined using a handheld Global Positioning System Receiver (Garmin Etrax). Upon detection, the Global Position System (GPS) coordinates of the fish's location were noted (accuracy $\pm 5 \mathrm{~m}$ ).

\section{Hydrology, water quality and meteorological data}

Flow levels in the Incomati River system were determined from daily readings at the KNP gauging weir in the Incomati River. Water temperature, $\mathrm{pH}$ and conductivity were recorded daily in the Crocodile River, Komati River and below the confluence of the two rivers (in the Incomati River) using Eutech portable microprocessor-based water quality instruments. Meteorological data were gathered from a nearby weather station (TransvaalSugar Board, Komatipoort), including rainfall, minimum and maximum air temperatures.

\section{Data analysis}

Two fish that moved out of the study area into Mozambique shortly after tagging were excluded from the analysis. In addition, a third fish showed no movement for an extended period after tagging and was presumed dead and excluded from the analysis. Descriptive statistics for the entire study period (summer and winter) were based on more than
10 fixes per fish for 38 fish. GPS coordinates of the radiotracked tigerfish were used to calculate longest distances travelled and to determine home range sizes.

Bi-variate Gaussian or normal distribution kernel methods (Seaman \& Powell 1996; Silwerman 1986; Worton 1989) were used to plot home ranges. This group of methods is part of a more general group of parametric kernel methods that employ distributions other than the normal distributions as the kernel elements which are associated with each point in the set of location data. Because of the meandering nature and relatively small width and limited available habitat within the Incomati River system during low flow periods at specific sites, an adaptation of the simplified minimum convex polygon (MCP) (Baker 2002; Creel \& Creel 2002; Meulman \& Klomp 1999) was used. Boundaries of home ranges were drawn using different sets of location data (Planet GIS). This method of using the shoreline as a boundary of the home range is a widely accepted and commonly used method in fish telemetry experiments (Hocutt et al. 1994).

For ease of statistical analysis, a binning algorithm was implemented in which the longest distance travelled, home range size and the radio-tagged fish were grouped in classes according to their magnitude. For longest distance travelled (Økland et al. 2005), fish were organised in classes ranging from $100 \mathrm{~m}$ to $500 \mathrm{~m}, 501 \mathrm{~m}$ to $1000 \mathrm{~m}, 1001 \mathrm{~m}$ to $1500 \mathrm{~m}$, $1501 \mathrm{~m}$ to $2000 \mathrm{~m}$ and $>2000 \mathrm{~m}$ travelled. The home range size were classed in groups ranging from $0 \mathrm{~m}^{2}$ to $10000 \mathrm{~m}^{2}$, $10001 \mathrm{~m}^{2}$ to $20000 \mathrm{~m}^{2}, 20001 \mathrm{~m}^{2}$ to $50000 \mathrm{~m}^{2}, 50001 \mathrm{~m}^{2}$ to $100000 \mathrm{~m}^{2}$ and $>100000 \mathrm{~m}^{2}$. 
The IBM SPSS Statistics 18 program was used for basic and inferential statistics which include frequencies, normality, correlations and comparisons (SPSS 2009).

\section{Ethical consideration}

The project proposal was approved with Ethical Clearance by the Faculty of Science, University of Johannesburg and Mpumalanga Parks and Tourism (Permit number MPB 8553.).

\section{Results}

\section{Water quality, hydrology and meteorological data}

Mean water temperature results in the Incomati River system indicate that the minimum is reached in July $\left(18.02{ }^{\circ} \mathrm{C}\right)$ after which temperatures gradually increase to a mean temperature of $24{ }^{\circ} \mathrm{C}$ during October. The highest mean monthly river water temperature during this study $\left(30.61^{\circ} \mathrm{C}\right)$ was recorded in the Crocodile River during January (Figure 3). The highest mean monthly river water temperature in the Komati River $\left(30.17{ }^{\circ} \mathrm{C}\right)$ was recorded during February. Temperatures in the Incomati River, below the confluence, were influenced by both tributaries, and consequently, the highest mean monthly temperature for the Incomati River $\left(28.88{ }^{\circ} \mathrm{C}\right)$ was recorded during February.

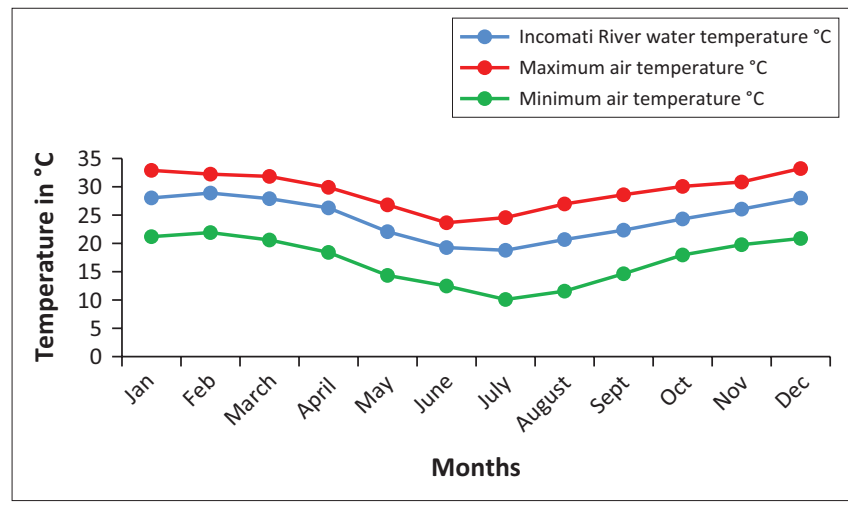

FIGURE 3: Graph indicating water and air temperature for the months January-December 2003 in the Incomati River.

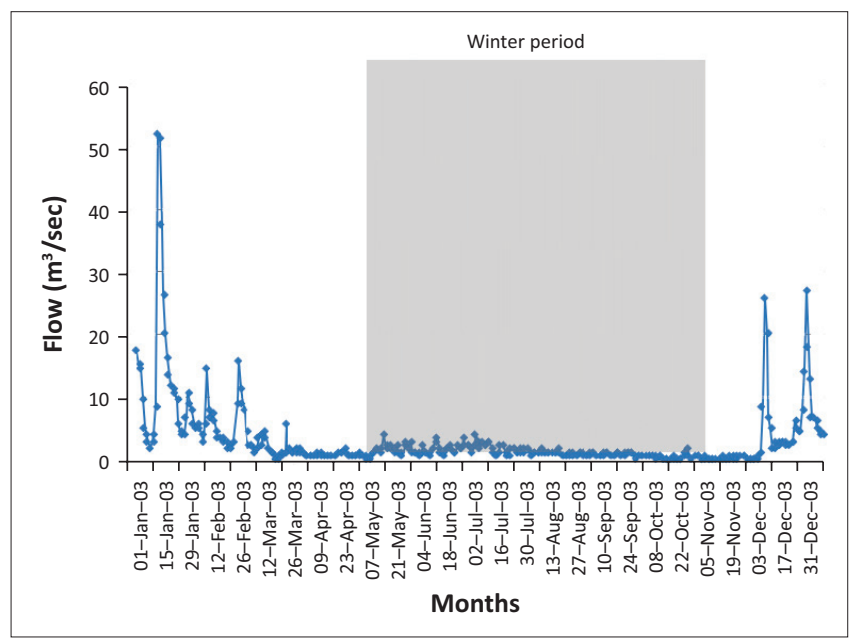

FIGURE 4: Water flow in the Incomati River over the period January-December 2003.
For the tigerfish active summer period, November to April, the mean monthly $\mathrm{pH}$ values varied between 8.1 and 8.5, whereas the conductivity fluctuated between $274 \mu \mathrm{S} / \mathrm{cm}$ and $622 \mu \mathrm{S} / \mathrm{cm}$ in the Incomati River. Summer conductivity values were lower than winter values, but summer $\mathrm{pH}$ values were higher. During summer, the turbidity levels increased as a result of the higher summer flows. Although not measured, turbidity was observed to be closely associated with rainfall events in the catchment during the summer period. The highest rainfall recorded was during the months of November $(115.4 \mathrm{~mm})$ and February $(191.7 \mathrm{~mm})$.

The mean monthly flow (Figure 4) for the winter period (May-October) in the Incomati River, when tigerfish are less active, varied between $0.44 \mathrm{~m}^{3} / \mathrm{s}$ and $1.89 \mathrm{~m}^{3} / \mathrm{s}$ compared to $0.82 \mathrm{~m}^{3} / \mathrm{s}$ and $13.12 \mathrm{~m}^{3} / \mathrm{s}$ for the summer period (NovemberApril), when tigerfish are active. The highest flow spikes were recorded during the spawning season (October-February) in the summer period (Steyn 1993; Steyn \& Van Vuren 1991; Steyn et al. 1996). On three occasions, flow spikes in excess of 25.00 $\mathrm{m}^{3} / \mathrm{s}$, with the largest of $51.76 \mathrm{~m}^{3} / \mathrm{s}$, occurred in January (Figure 4).

\section{Radio-tagged fish}

In total, 41 fish were radio-tagged with a mean length (SL) of $62.7 \mathrm{~cm}$ (range $47 \mathrm{~cm}-76 \mathrm{~cm}$ ) and a mean weight of $2418 \mathrm{~g}$ (range $910 \mathrm{~g}-4990 \mathrm{~g}$ ) (Table 1; Figure 2). Of the 41 radiotagged fish, $11(26.8 \%)$ were males and $30(73.2 \%)$ were females in a 1:3 sex ratio. For the radio-tagged males, the length (SL) varied between $47 \mathrm{~cm}$ and $60 \mathrm{~cm}($ mean $=55.4 \mathrm{~cm})$ and the weight varied between $910 \mathrm{~g}$ and $2040 \mathrm{~g}$ (mean = $1605.5 \mathrm{~g}$ ). For the radio-tagged females, the length (SL) ranged from $57 \mathrm{~cm}$ to $76 \mathrm{~cm}$ (mean $=65.4 \mathrm{~cm})$ and the weight ranged from $1810 \mathrm{~g}$ to $4990 \mathrm{~g}$ (mean $=2717 \mathrm{~g}$ ) (Table 2).

\section{Movement}

The total distance of the river where adult fish were captured and equipped with radio tags measured $5.2 \mathrm{~km}$. After capture, tagging and the associated disturbance to a fish when released, the fish normally moved upstream or downstream and normally only returned 2 to 5 days later to the original tagging site, thereby suggesting site fidelity. The distance moved directly after tagging varied over the 2- to 5-day period from $48 \mathrm{~m}$ to $1038 \mathrm{~m}$. In total, 35 (85.4\%) of the fish tagged returned to the original tagging site within the mentioned period, but $6(14.6 \%)$ never returned, 3 of which moved downstream into Mozambique and were not recorded again. This showed angling in the form of catch and release may be a major disturbance, but this also confirmed site fidelity of tigerfish to a specific home range. The GPS coordinates of each sample or release site, tag number, type of tag and size, weight and sex of each fish are presented in Table 1. Over time, a movement pattern emerged for each of the 41 radio-tagged fish, and the longest distances travelled and home ranges could be determined (Table 1).

On average, fish were tracked 72.5 times (Table 2) and the total number of fixes was 2971 for the period 04 January 2003 
TABLE 2: Summary of average fish length, number of fixes, longest distance travelled and home range.

\begin{tabular}{|c|c|c|c|c|c|c|c|c|c|c|c|c|}
\hline \multirow[t]{2}{*}{ Description } & \multicolumn{4}{|c|}{ Female } & \multicolumn{4}{|c|}{ Male } & \multicolumn{4}{|c|}{ All fish } \\
\hline & Variable & SD & $n$ & $\%$ & Variable & SD & $n$ & $\%$ & Variable & SD & $n$ & $\%$ \\
\hline \multicolumn{13}{|l|}{ Weight and length } \\
\hline Mean length $(\mathrm{cm})(\mathrm{SL})$ & 65.4 & - & 30 & - & 55.4 & - & 11 & - & 62.7 & 6.581 & 41 & \\
\hline Range for length $(\mathrm{cm})$ & $57-76$ & - & - & - & $47-60$ & - & - & - & $47-76$ & - & - & \\
\hline Mean weight (g) & 2717 & 808.274 & 30 & - & 1605.5 & 308.286 & 11 & - & 2418.8 & 883.409 & 41 & \\
\hline Range for weight (g) & $1810-4990$ & - & - & - & $910-2040$ & - & - & - & $910-4990$ & - & - & \\
\hline \multicolumn{13}{|l|}{ Number of fixes } \\
\hline Mean number of fixes & 78.4 & - & 30 & - & 56.2 & - & 11 & - & 72.5 & 47.694 & 41 & - \\
\hline Range for fixes & $6-161$ & - & - & - & $7-110$ & - & - & - & $6-161$ & - & - & - \\
\hline Summer fixes & - & - & - & - & - & - & - & - & 1322 & - & - & - \\
\hline Winter fixes & - & - & - & - & - & - & - & - & 1649 & - & - & - \\
\hline Total number of fixes & - & - & - & - & - & - & - & - & 2971 & - & - & - \\
\hline \multicolumn{13}{|l|}{ Longest distance travelled } \\
\hline Mean longest distance travelled (m) & 734.43 & 653.062 & 28 & - & 716.29 & 602.841 & 10 & & 729.66 & 632.208 & 38 & - \\
\hline \multicolumn{13}{|l|}{ Longest distance travelled (m) } \\
\hline $100-500$ & 13 & - & 28 & 46.40 & 5 & - & 10 & 50.00 & 18 & - & 38 & 47.37 \\
\hline $501-1000$ & 11 & - & - & 39.30 & 2 & - & - & 20.00 & 13 & - & - & 34.20 \\
\hline 1001-1500 & 2 & - & - & 7.10 & 2 & - & - & 20.00 & 4 & - & - & 10.50 \\
\hline 1501-2000 & 1 & - & - & 3.60 & 1 & - & - & 10.00 & 2 & - & - & 5.26 \\
\hline$>2000$ & 1 & - & - & 3.60 & 0 & - & - & 0.00 & 1 & - & - & 2.63 \\
\hline \multicolumn{13}{|l|}{ Home range } \\
\hline Mean home range $\left(\mathrm{m}^{2}\right)$ & 53296.52 & 67038.441 & 28 & & 36385.90 & 48518.772 & 10 & & 48846.36 & - & 38 & - \\
\hline Range for home range $\left(\mathrm{m}^{2}\right)$ & $331.6-236496$ & & & & 1338.8-135982.6 & & & & $331.6-234496$ & - & - & - \\
\hline \multicolumn{13}{|l|}{ Home range size $\left(m^{2}\right)$} \\
\hline $0-10000($ mean $=5567.95)$ & 9 & - & 28 & 32.10 & 4 & - & 10 & 40.00 & 13 & - & 38 & 38.20 \\
\hline $10001-20000($ mean = 14 435.53) & 4 & - & - & 14.30 & 3 & - & - & 30.00 & 7 & - & - & 18.42 \\
\hline $20001-50000($ mean = 31092.2$)$ & 7 & - & - & 25.00 & 0 & - & - & 0.00 & 7 & - & - & 18.42 \\
\hline $50001-100000($ mean = 79 808.55 $)$ & 2 & - & - & 7.10 & 2 & - & - & 20.00 & 4 & - & - & 10.50 \\
\hline
\end{tabular}

Total length/weight for 41 fish, for statistical analysis only 38 fish used.

$\mathrm{SL}$, standard length.

to 22 December 2003. Some individuals were tracked up to 161 times. The maximum total of fixes $(n=161)$ per individual was associated with a tag life of 10 months. For the summer period (January-April, November and December 2003), there were 1322 fixes, and for the winter period (May-October 2003), there were 1649 fixes. For the summer period (or part thereof), there were 40 active radio-tagged fish, but only 32 active radio-tagged fish for the winter period (or part thereof). The mean number of fixes for females was $78.4(n=30)$ per fish with a range of $6-161$. The mean number of fixes for males was $56.2(n=11)$ per fish with a range of $7-110$. The reason for the lower amount of fixes for males (56.2 fixes) in comparison with females (78.4 fixes) can be ascribed to the differences in radio tag types used. As males are generally smaller than females, smaller F2040 radio tags, with a much shorter lifespan (94 days), were used to stay within the $2 \%$ rule.

\section{Longest distance travelled}

For the statistical analysis, data were obtained from 38 radiotagged tigerfish with more than 10 fixes. The mean longest distance travelled $(n=38)$ was $729.66 \mathrm{~m}$ (Table 2$)$ with a range from $74.5 \mathrm{~m}$ to $3200 \mathrm{~m}$. When analysing the longest distance travelled by the different radio-tagged fish, $47.4 \%$ (18 out of the 38 fish) travelled between $100 \mathrm{~m}$ and $500 \mathrm{~m}$, $34.2 \%$ (13 fish) between $501 \mathrm{~m}$ and $1000 \mathrm{~m}, 10.5 \%$ (4 fish) between $1001 \mathrm{~m}$ and $1500 \mathrm{~m}, 5.3 \%$ (2 fish) between $1501 \mathrm{~m}$

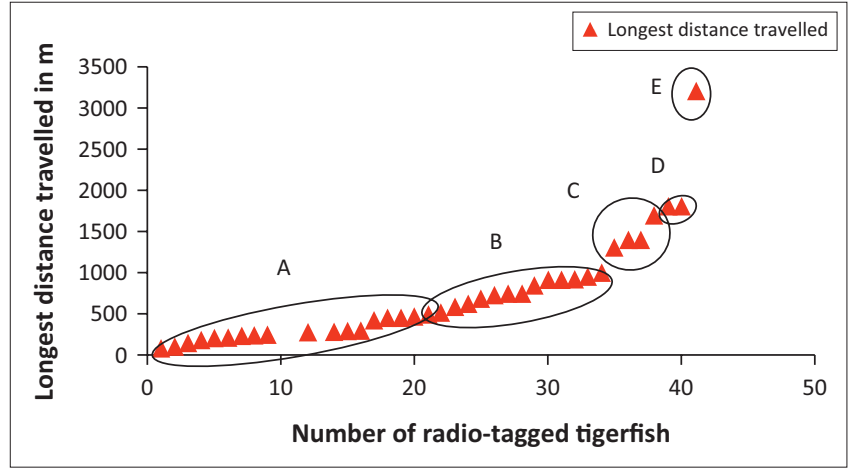

FIGURE 5: Clustering of longest distance travelled of radio-tagged tigerfish for the period January-December 2003. A, 0 m-500 m; B, 501 m-1000 m; C, $1001 \mathrm{~m}-1500 \mathrm{~m} ; \mathrm{D}, 1501 \mathrm{~m}-2000 \mathrm{~m} ; \mathrm{E},>2000 \mathrm{~m}$.

and $2000 \mathrm{~m}$ and $2.6 \%$ (1 fish) travelled more than $2000 \mathrm{~m}$ (Table 2; Figure 5).

When distinguishing between the different sexes and longest distance travelled, $46.4 \%$ of females (13 out of 28 fish) travelled between $100 \mathrm{~m}$ and $500 \mathrm{~m}, 39.3 \%$ (11 fish) between $501 \mathrm{~m}$ and $1000 \mathrm{~m}, 7.1 \%$ (2 fish) between $1001 \mathrm{~m}$ and $1500 \mathrm{~m}$, 3.6\% (1 fish) between $1501 \mathrm{~m}$ and $2000 \mathrm{~m}$ and 3.6\% (1 fish) travelled more than $2000 \mathrm{~m}$. For the males, 50\% (5 out of 10 fish) travelled between $100 \mathrm{~m}$ and $500 \mathrm{~m}, 20 \%$ (2 fish) between $501 \mathrm{~m}$ and $1000 \mathrm{~m}, 20 \%$ (2 fish) between $1001 \mathrm{~m}$ and $1500 \mathrm{~m}$ and $10 \%$ (1 fish) between $1501 \mathrm{~m}$ and $2000 \mathrm{~m}$ (Table 2). 
The furthest movement recorded was 3200 m over a 3-day period. This female moved out of its known home range (18 fixes) and established a new home range approximately $3018 \mathrm{~m}$ upstream (Table 2).

For females, the mean longest distance travelled was $734.4 \mathrm{~m}$ $(n=28)$ with a range of $74.5 \mathrm{~m}$ to $3200 \mathrm{~m}$, and for males, the mean longest distance travelled was $716.3 \mathrm{~m}(n=10)$ with a range of $148.9 \mathrm{~m}$ to $1800 \mathrm{~m}$. No significant differences were found between males and females for longest distances travelled (Mann-Whitney U test, mean ranking males 19.8 and females 18.6, $p=0.753$ ).

Three different tigerfish movement patterns were recorded (Figure 6). Movement patterns were obtained from a combined effect of distance travelled and home range sizes (Figure 7). Although all the fish displayed some degree of site fidelity within a specific activity zone, movement pattern 1 represents fish that moved $100 \mathrm{~m}$ to $500 \mathrm{~m}$ within a well-defined home range, and movement occurred only within this specific home range. Movements of fish number 8 serves as example

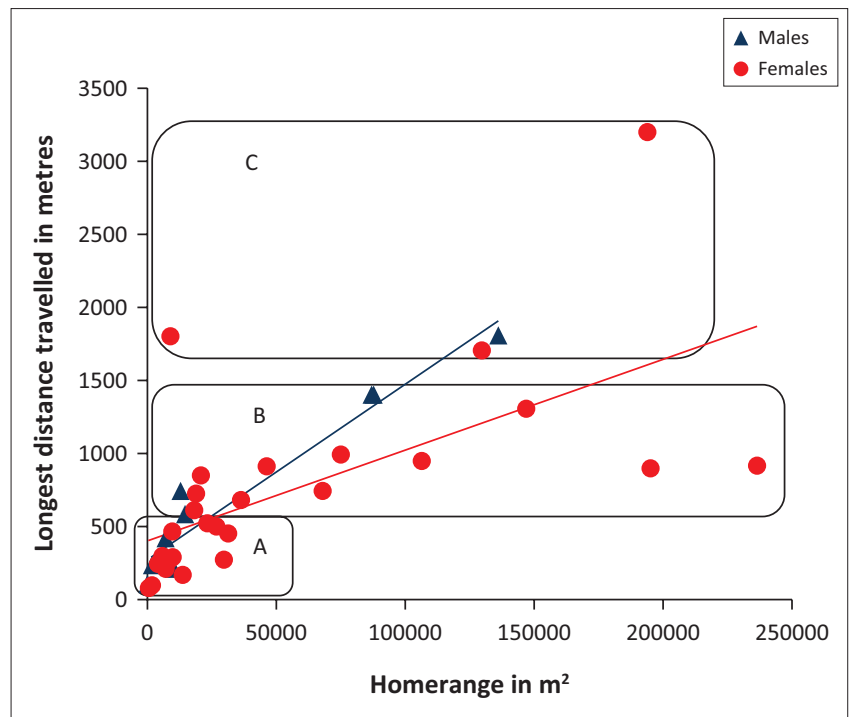

Cluster A represents type 1 movement pattern; Cluster B represents type 2 movement pattern; and Cluster $C$ represents type 3 movement pattern.

FIGURE 6: Scatter graph depicting three different movement patterns by radiotagged tigerfish related to home range size and longest distance travelled for the study period January-December 2003.

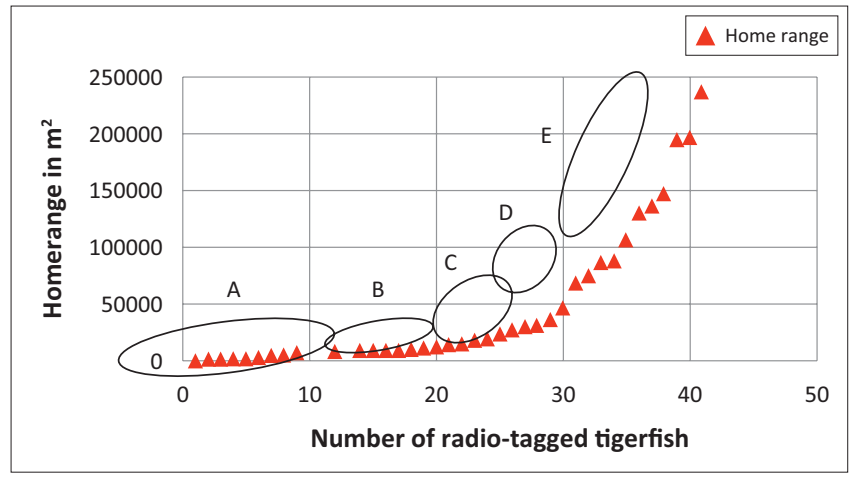

FIGURE 7: Clustering of home range sizes of radio-tagged fish. A, $0 \mathrm{~m}^{2}-10000 \mathrm{~m}^{2}$ B, $10001 \mathrm{~m}^{2}-20000 \mathrm{~m}^{2}$; C, $20001 \mathrm{~m}^{2}-50000 \mathrm{~m}^{2}$; D, $50001 \mathrm{~m}^{2}-100000 \mathrm{~m}^{2}$; $\mathrm{E},>100000 \mathrm{~m}^{2}$. for this type of movement pattern (Figure 8). The majority $(47.37 \%)$ of the radio-tagged fish displayed characteristics of movement pattern 1 (Figure 6, Cluster A). Movement pattern 2 represents fish that displayed site fidelity for two or more areas within a larger well-defined home range, spanning a distance of $501 \mathrm{~m}$ to $1500 \mathrm{~m}$. Movements of fish number 15 serve as example for this type of movement pattern (Figure 9). This group was represented by $44.7 \%$ of radiotagged fish (Figure 6, Cluster B). Movement pattern 3 represents fish that showed little site fidelity and would temporarily occupy small areas within a large undefined home range that spans more than $1500 \mathrm{~m}$. Movements of fish number 23 serve as example for this type of movement (Figure 10). Fish within the latter group can be seen as vagrants without established home ranges for a specific period. Most of these fish were also later lost as they moved out of the study area and could not be relocated. Fish in this group were large females of weight ranging between $2720 \mathrm{~g}$ and $3580 \mathrm{~g}$ and represented $7.89 \%$ of the radio-tagged fish (Figure 6, Cluster C).

For a detailed account of the movement patterns and demarcation of the home ranges of each of the 41 radiotagged fish, see Roux (2013). The dots indicate individual fixes during tracking and the contours around the fixes indicate the defined home range.

\section{Home range sizes}

The home range size varied between individual fish with $38.2 \%$ (13 fish) localising within an area between $0 \mathrm{~m}^{2}$ and $10000 \mathrm{~m}^{2}$ (mean $\left.=5567.95 \mathrm{~m}^{2}\right)$ and $18.42 \%$ (7 fish) localising within an area between $10001 \mathrm{~m}^{2}$ and $20000 \mathrm{~m}^{2}$ (mean = $14435.53 \mathrm{~m}^{2}$ ). Furthermore, 18.42\% (7 fish) occupied a home range area between $20001 \mathrm{~m}^{2}$ and $50000 \mathrm{~m}^{2}$ (mean = $31092.2 \mathrm{~m}^{2}$ ), whereas $10.5 \%$ (4 fish) occupied an area between $50001 \mathrm{~m}^{2}$ and $100000 \mathrm{~m}^{2}$ (mean $\left.=79809.55 \mathrm{~m}^{2}\right)$ and $18.42 \%$ (7 fish) utilised an area $>100000 \mathrm{~m}^{2}\left(\right.$ mean $\left.=163692.90 \mathrm{~m}^{2}\right)$ (Table 2; Figure 7).

On average, the fish $(n=38)$ stayed within a defined home range of $48846.36 \mathrm{~m}^{2}$. The home range size for males and females compared favourably with a mean of $53296.52 \mathrm{~m}^{2}$ $(n=28)$ and a range from $331.6 \mathrm{~m}^{2}$ to $236496 \mathrm{~m}^{2}$ for females and a mean of $36385.9 \mathrm{~m}^{2}(n=10)$ and a range from $1338.8 \mathrm{~m}^{2}$ to $135982.6 \mathrm{~m}^{2}$ for males. No statistically significant differences were found between the sexes for their home range size (Mann-Whitney U test, mean ranking females $=20.71$ and males $=16.10, p=0.260$ ).

\section{Migration obstructions}

None of the 41 tagged fish crossed the Tenbosch weir. Three individuals, namely numbers 7, 12 and 18, moved upstream in the Crocodile River to be briefly recorded in the vicinity of this weir. The Tenbosch weir has a crest height of $2 \mathrm{~m}$ and a fish ladder constructed at the side of the weir. This ladder is of the vertical slot type and appears to be non-functional to fish migration in general. 


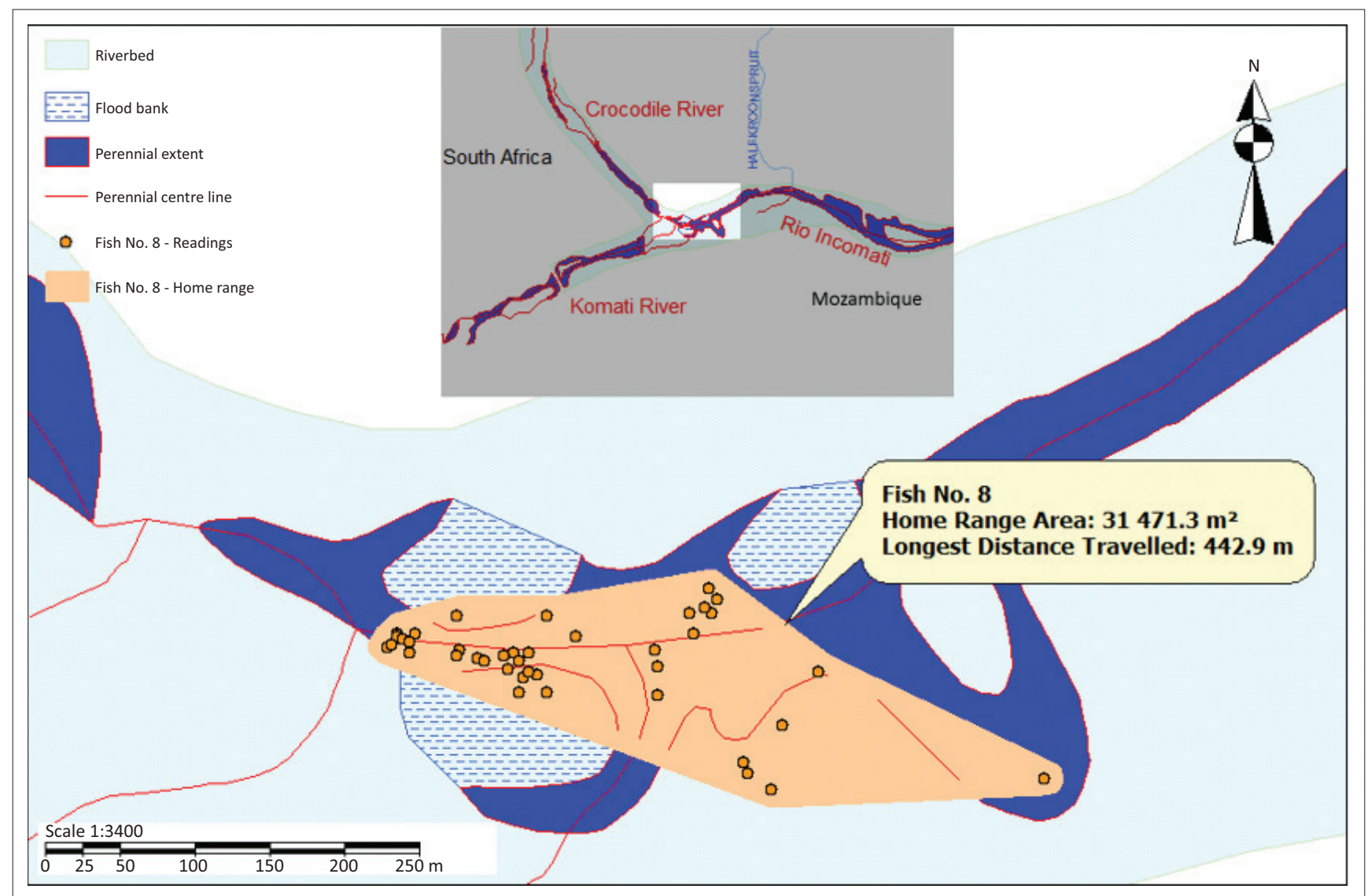

FIGURE 8: Map of radio-tagged fish number 8 indicating home range and longest distance travelled (Type 1 movement pattern).

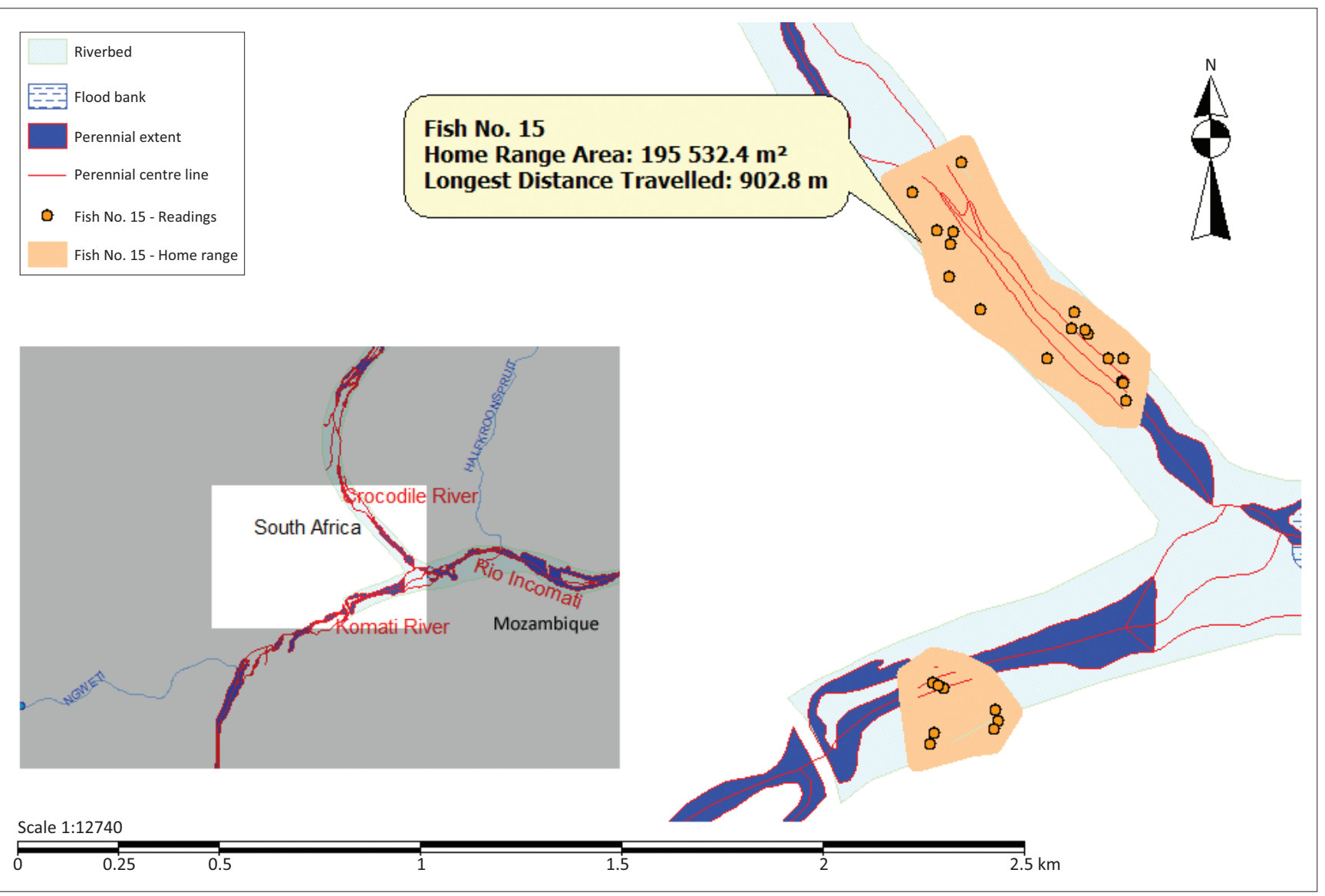

FIGURE 9: Map of radio-tagged fish number 15 indicating home range and longest distance travelled (Type 2 movement pattern). 


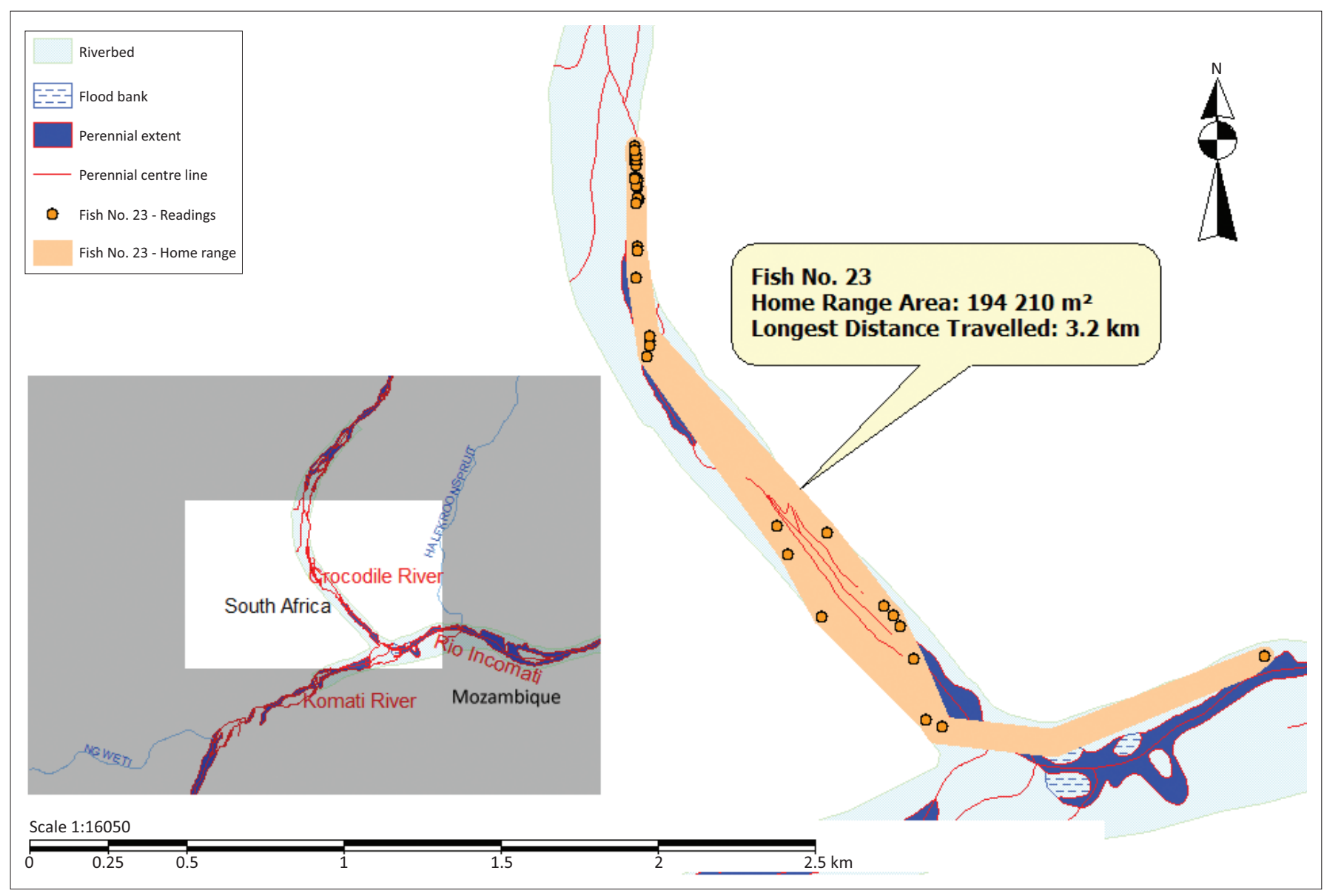

FIGURE 10: Map of radio-tagged fish number 23 indicating home range and longest distance travelled (Type 3 movement pattern)

Only two radio-tagged fish (fish numbers 15 and 39) ventured into the lower Komati River, close to the confluence with the Crocodile River, where they were confined in a pool below the low-water bridge for a few days. They were not able to overcome this obstacle. This low-water bridge at Komatipoort was constructed on a natural dolerite intrusion that stretches across the river.

Contrary to the above, a total number of 16 crossings, both upstream and downstream, were recorded at the KNP weir. This gauging weir has a crest height of approximately $1.2 \mathrm{~m}$ with a well-designed fish way to facilitate fish movement at medium to high flow conditions. Tagged fish with allocated numbers 1, 4, 6, 20, 27 and 37 crossed the KNP weir downstream and upstream over the period January to March, whereas fish 19 crossed the KNP weir downstream during July and returned upstream three days later. Fish numbers 1 and 27 each crossed on three occasions, whereas fish number 20 crossed the KNP weir on four occasions with only a few day intervals between upstream and downstream crossings. Numerous visual observations were made of untagged tigerfish jumping over this weir over the duration of this study. Successful crossing at the KNP weir occurred at flow velocities between $1.78 \mathrm{~m}^{3} / \mathrm{s}$ and $16.2 \mathrm{~m}^{3} / \mathrm{s}$ (Table 3 ).

\section{Discussion}

This study confirmed that external tagging attachment protocol (Thorstad et al. 2001) was suitable for the study of tigerfish behavioural ecology through biotelemetry in that only a single mortality was recorded from the 41 radio-tagged fish. Furthermore, visual observations of radio-tagged fish swimming just below the surface were made on numerous occasions and fouling of radio tags appeared to be minimal, thus having no significant effect on the swimming capabilities or movement patterns of tagged fish.

After capture, tagging and the associated disturbance to a fish, it normally moved either upstream or downstream and returned 2-5 days later to the original tagging site, thereby confirming site fidelity. The distance moved directly after tagging varied over the 2- to 5-day period from $48 \mathrm{~m}$ to $1038 \mathrm{~m}$. In total, 35 of the tagged fish returned to the original tagging site within the mentioned time frame. Six fish never returned; three of these moved downstream into Mozambique and were lost.

In general, tigerfish displayed high site fidelity to specific habitats within specific activity zones, and movement occurred primarily within these defined home ranges. The longest distance travelled by fish was during summer and early winter, when water temperatures exceeded $24{ }^{\circ} \mathrm{C}$. These periods coincided with high water levels in the study area, which probably facilitated movement between different habitats. Some degree of site fidelity of $H$. vittatus was also reported by Økland et al. (2005) for the Upper Zambezi, 
TABLE 3: Successful crossings of radio-tagged tigerfish at the Kruger National Park weir.

\begin{tabular}{|c|c|c|c|c|c|c|c|c|}
\hline Fish number & Upstream & $\begin{array}{l}\text { Flow velocity } \\
\left(\mathrm{m}^{3} / \mathrm{s}\right)\end{array}$ & Downstream & $\begin{array}{l}\text { Flow velocity } \\
\left(\mathrm{m}^{3} / \mathrm{s}\right)\end{array}$ & Upstream & $\begin{array}{l}\text { Flow velocity } \\
\left(\mathrm{m}^{3} / \mathrm{s}\right)\end{array}$ & Downstream & $\begin{array}{l}\text { Flow velocity } \\
\left(\mathrm{m}^{3} / \mathrm{s}\right)\end{array}$ \\
\hline $1 \dagger$ & 04 January 2003 & 9.847 & 17 January 2003 & 16.202 & 19 January 2003 & 11.861 & - & - \\
\hline $4 \dagger$ & 28 January 2003 & 10.818 & 24 February 2003 & 15.827 & - & & - & - \\
\hline $6 \dagger$ & 23 January 2003 & 5.880 & - & - & - & & - & - \\
\hline $19 \%$ & - & - & 20 July 2003 & 1.783 & 23 July 2003 & 1.944 & - & - \\
\hline $20 \dagger$ & 19 January 2003 & 11.861 & 24 January 2003 & 4.456 & 01 February 2003 & 5.341 & 08 February 2003 & 8.138 \\
\hline $27 \%$ & - & - & 12 February 2003 & 4.559 & 28 February 2003 & 4.821 & 08 March 2003 & 4.235 \\
\hline $37 \$$ & - & - & 24 February 2003 & 15.827 & - & - & - & - \\
\hline
\end{tabular}

$\dagger$, Fish 1, 4, 6 and 20 were tagged downstream of the KNP weir; $\ddagger$, Fish 19, 27 and 37 were tagged upstream of the KNP weir and recorded to cross the KNP weir (upstream and downstream). KNP, Kruger National Park.

whereas consistent fidelity to an activity core was reported by Baras et al. (2002) for Hydrocynus brevis in the Niger River, Mali.

During our study, little to no movement was recorded in the winter months when water temperatures were below $24{ }^{\circ} \mathrm{C}$. The mean lowest temperature recorded in the Incomati River system of $18{ }^{\circ} \mathrm{C}$ is close to the minimum temperature range for the survival of tigerfish. During a tigerfish translocation exercise when laboratory-induced breeding was attempted, prior to successful breeding at Skukuza (Steyn et al. 1996), a temperature drop from $27{ }^{\circ} \mathrm{C}$ to $18{ }^{\circ} \mathrm{C}$ during a 4-hour transport period killed almost all of the fish.

The mean longest distance travelled during this investigation was relatively short $(729.66 \mathrm{~m})$. In the Zambezi, two movement patterns were distinguished where approximately $50 \%$ of the fish moved $<1000 \mathrm{~m}$ among tracking surveys. The remaining fish showed consistent site fidelity for periods with longdistance movements (>1000 m) to new areas among residency periods. In the Incomati River system, only $18 \%$ of the fish displayed long-distance movement $>1000 \mathrm{~m}$ and the longest distance was $3200 \mathrm{~m}$. The longest distance travelled in the Incomati River system was relatively short in comparison with the longest distance of $18.8 \mathrm{~km}$ travelled in the Zambezi River (Økland et al. 2005). Irrespective of the shorter distances travelled in the Incomati River system, the total unobstructed river upstream to Tenbosch was not utilised by all tagged individuals and the option to migrate downstream was available but not utilised. Nevertheless, three movement patterns demonstrated by Incomati River system tigerfish do not describe the dependency on upstream or downstream migration behaviour expected for this species in the study area.

Implicit of the relative short distances travelled, they are crucial for the survival of $H$. vittatus in the lower Incomati River system. Site fidelity and restricted mean home range $\left(48846 \mathrm{~m}^{2}\right)$ in comparison with the much larger home range of Zambezi tigerfish (276978 $\left.\mathrm{m}^{2}\right)$, supported by various historical observations of their vulnerability to environmental stressors such as low temperature, low flow and high silt loads, are indicative of a population that does not function optimally on the edge of its distribution, in accordance with the law of tolerance (Odum 1971). Sub-optimal functionality of another tigerfish population in the KNP is also reflected in the results of Gagiano (1997), during an ecological investigation on tigerfish in the Olifants and Letaba Rivers. Tigerfish of all sizes in these rivers were found to feed almost exclusively on invertebrates. This finding is in contrast with the tigerfish from other systems, where fish play a major role in their diet (Jackson 1961).

Differences in movement patterns, longest distance travelled and home range size could not be explained by sex or the size of the fish. Tigerfish show opportunistic movement patterns, and home ranges can change in size and location as a result of seasonal shifts, prey availability, habitat availability and cover as well as life history requirements.

No large-scale movement pattern or specific activity-related migrations were observed. Thus, reports of large-scale migrations of tigerfish downstream into Mozambique during winter in the Incomati River (Van Loggerenberg 1982) seem to be no longer relevant, probably because of their limited numbers and because of suitable habitat created by the damming of the KNP weir and subsequent deeper water bodies where the temperature is more stable to find refuge during winter. There was no evidence of upstream congregation of tigerfish at the Tenbosch weir or large-scale downstream crossings at the KNP weir.

From the pattern of crossings at the KNP weir, it is inferred that some of the marked fish that successfully crossed this weir responded to the stress associated with the tagging procedure and returned later to demonstrate site fidelity. These fish were tagged either just downstream or upstream of the KNP weir, followed by a fleeing response over the weir (fish numbers 1 , 6,19 and 20). Some of the crossings could be associated with higher flow conditions (fish numbers 4 and 37), whereas fish number 27 probably displayed natural behaviour as the crossing occurred more than a month after tagging. Irrespective of the motivation for crossing the weir, in context with the life span of the tags for above fish, these events were limited to only a few occasions during a period of several months, which again displayed site fidelity. Flow volumes that varied between $1.94 \mathrm{~m}^{3} / \mathrm{s}$ and $16.22 \mathrm{~m}^{3} / \mathrm{s}$ during successful crossings suggest that the KNP weir is not a restrictive barrier to tigerfish and the population is open to gene flow from Mozambique. Contrary to this, our results suggest that tigerfish in the Crocodile River, upstream from the Tenbosch weir, is isolated; consequently, the upstream population cannot be replenished after mortalities because of extreme environmental conditions such as influx of cold water, low flow and high silt loads and will most probably disappear in this part of its historical distribution range. 
In the Komati River, upstream movement is restricted close to the confluence at the low-water bridge, consequently isolating the upstream population in the Komati River which currently is heavily subjected to water abstraction and agricultural activities. The isolation of upstream tigerfish populations in the Incomati River system and their vulnerability to environmental impacts emphasise the ecological significance and inclusion of this river reach into the borders of the KNP as well as the functionality and importance of the KNP weir.

Based on the knowledge gained during this study on the behaviour of tigerfish, recommendations on the instream flow requirements (IFRs) of this species need to be adopted into the ecological flow requirements for the Incomati River system and setting of the Ecological Reserve to ensure the ecological maintenance and functioning of the instream habitats utilised by tigerfish (Kleynhans \& Engelbrecht 2000). Environmental flow allocations and maintenance of ecological requirements of aquatic ecosystems are entrenched in the National Water Act (No 36 of 1989) and specified as components of the ecological reserve. Within the framework of Resource Directed Measures for Protection of Water Resources, established by the Department Water Affairs and Sanitation (DWA), the implemented ecological reserve needs to be monitored and can be adjusted to meet the targets and resource quality objectives (King, Tharme \& De Villiers 2000).

\section{Acknowledgements}

The authors acknowledge De Beers, Venetia Mines and Barloworld for funding this project. They thank the Incomati Tigerfish Action Group (iTag), Domien and Bart van Buynder for their logistical support and for their enthusiasm for the tigerfish species and its conservation. They also thank Peter Kimberg and Michael Mashaba for their assistance with fieldwork and data collection.

\section{Competing interests}

The authors declare that they have no financial or personal relationships that may have inappropriately influenced them in writing this article.

\section{Authors' contributions}

F.R. was the researcher who performed most of the sampling and data analysis. G.S. was the researcher who was responsible for the experimental design. C.H. was the co-worker who is a fish expert with experience in biotelemetry. I.W. was the promoter of the PhD study, made conceptual contributions and proofread the manuscript. F.R. and G.S. wrote the manuscript.

\section{References}

Albaster, J.S. \& Lloyd, R., 1980, Water quality criteria for freshwater fish, FAO, United Nations, London.

Baker, J., 2002, 'Population density and home range estimates for the eastern bristlebird at Jervis Bay, south-eastern Australia', Corella 25, 62-67.

Baras, E., Togola, B., Sicard, B. \& Benech, V., 2002, 'Behaviour of tigerfish Hydrocynus brevis in the River Niger, Mali, as revealed by simultaneous telemetry of activity and swimming depth', Hydrobiologia 483, 103-110. https://doi.org/10.1023/ A: 1021359008246
Baras, E. \& Lucas, M.C., 2002, 'Impacts of man's modification of river hydrology on the migration of freshwater fishes: A mechanistic perspective', Ecohydrology and Hydrobiology 146, 431-448.

Buermann, Y., Du Preez, H.H., Steyn, G.J., Harmse, J.T. \& Deacon, A., 1995, 'Suspended silt concentrations in the lower Olifants River (Mpumalanga) and the impact of silt releases from the Phalaborwa Barrage on water quality and fish survival', Koedoe 38(2), 11-33. https://doi.org/10.4102/koedoe.v38i2.312

Brown, R.S., Cooke, S.J., Anderson, W.G. \& McKinley, R.S., 1999, 'Evidence to challenge the " $2 \%$ Rule" for biotelemetry', North American Journal of Fisheries Management 19, 867-871. https://doi.org/10.1577/1548-8675(1999)019<0867:ETCTRF>2.0.CO;2

Bruton, M.N., 1985, 'The effects on suspensoids on fish', Hydrobiologia 125, 221-241. https://doi.org/10.1007/BF00045937

Creel, S. \& Creel, N.M., 2002, The African wild dog: Behaviour, ecology and conservation, Princeton University Press, New Jersey.

Crouse, M.R., Callahan, H.F. \& Malaug, K.W., 1981, 'Effects of fine sediments on growth of juvenile Coho salmon in laboratory streams', Transactions American Fisheries Society 110, 281-286. https://doi.org/10.1577/1548-8659(1981)110<281:EOFSOG> 2.0.CO;2

Darwall, W.R.T., Smith, K.G., Tweddle, D. \& Skelton, P.H., 2009, The status and distribution of freshwater biodiversity in southern Africa, IUCN and Grahams town, South Africa: SAIAB, Gland, Switzerland, p. 120

Deacon, A., 1991, '“Visvrektes in Olifantsrivier" (Fish mortality in Olifants River)', Custos 18, 31.

Du Preez, H.H. \& Steyn, G.J., 1992, 'A preliminary investigation of the concentration of selected metals in the tissues and organs of tigerfish (Hydrocynus vittatus) from the Olifants River, Kruger National Park, South Africa', Water SA 18(2), from the

Gagiano, C.L., 1997, 'An ecological study on the tigerfish Hydrocynus vittatus in the Olifants and Letaba rivers with special reference to artificial reproduction' Unpublished master's dissertation, Rand Afrikaans University, Johannesburg, viewed 05 September 2014 from http://hdl.handle.net/10210/7031

Gagiano, C.L., Steyn, G.J. \& Du Preez, H.H., 1996, 'Tooth replacement of tigerfish Hydrocynus vittatus from the Kruger National Park', Koedoe 38(1), 1-6.

Gaigher, I.G., 1967, 'Aspects of the ecology of the tigerfish, Hydrocynus vittatus Castlenau in the Incomati River system', Unpublished master's dissertation, University of Pretoria, Pretoria.

Gaigher, I.G., 1970, 'Ecology of the tigerfish (Hydrocynus vittatus) in the Incomati River system, South Africa', Zoologica Africana 5(2), 211-227. https://doi.org/10.1080/ 00445096.1970 .11447393

Gaigher, I.G., 1973, 'The habitat preferences of fishes from the Limpopo River system, Transvaal and Mozambique', Koedoe 16, 103-116. https://doi.org/10.4102/koedoe. v16i1.888

Gaigher I.G., 1975, 'Evidence for tooth replacement in the tigerfish Hydrocynus vittatus', Arnoldia Rhodesia 7(1), 1-4.

Gery, J., 1977, Characoids of the world, T.F.H. Publications, New York, p. 672.

Gerber, R., Howatson, G., Greenfield, R., Wagenaar, I. \& Smit, N., 2017, 'Physiological response to angling of Africa's premier angling species, the tigerfish Hydrocynus vittatus', Journal of African Zoology 52(2), 91-98. https://doi.org/10.1080/15627 020.2017.1300069

Gerber, R., Smit, N.J., Pieterse, G.M. \& Durholtz, D., 2009, 'Age estimation, growth and size at sexual maturity of tigerfish Hydrocynus vittatus from the Okavango Delta, Botswana', African Journal of Aquatic Science 34(3), 239-247.

Gertenbach, W.P.D., 1991, Problems facing Kruger National Park: First annual research meeting, 19-20 March 1991, Programme Report 2, 1-4, Kruger National Park, Skukuza.

Hocutt, C.H., Seibold, S.E. \& Jesien, R.V., 1994, 'Potential use of biotelemetry in tropical continental waters', Revue d'hydrobiologie Tropicale, Paris 27, 77-95.

Jackson, P.B.N., 1961, 'The impact of predation, especially by Tigerfish, Hydrocynus vittatus, on African freshwater fishes', Proceedings of the Zoological Society London 136(4), 603-622. https://doi.org/10.1111/j.1469-7998.1961.tb05895.x

Jick, T.D., 1979, 'Mixing qualitative and quantitative methods: Triangulation in action', Administrative Science Quarterly 24, 602-611. https://doi.org/10.2307/2392366

King, J.M., Tharme, R.E. \& De Villiers, M.S., 2000, Environmental flow assessments for rivers: Manual for the building block methodology, WRC Report No: TT 131/60, Water Research Commission, Pretoria, p. 340.

Kruger National Park, Annual Reports, 1946-1992, Unpublished Report, National Parks Board.

Meulman, E.P. \& Klomp, N.I., 1999, 'Is the home range of the heath mouse Pseudomys shortridgei an anomaly in the Pseudomys genus?', Victorian Naturalist 116, 196-201.

Moore, C.A. \& Chutter, E.M., 1988, A survey of the conservation status and benthic biota of the major rivers of the Kruger National Park, Contract Report National Institute of Water Research, CSIR.

Odum, E.P., 1971, 'Fundamentals of ecology', Saunders, London.

$\emptyset$ kland, F., Thorstad, E.B., Hay, C.J., Naesje, T.F. \& Chanda, B., 2005, 'Patterns of movement and habitat use by tigerfish (Hydrocynus vittatus) in the Upper Zambezi River, Namibia', Ecology of Freshwater Fish 14, 79-86. https://doi.org/10.1111/ j.1600-0633.2004.00080.x

Peake, S. \& McKinley, R.S., 1997, 'Influence of transmitter attachment procedures on swimming performance of wild and hatchery-reared Atlantic salmon smolt' Transactions of the American Fisheries Society 126, 707-714. https://doi.org/ 10.1577/1548-8659(1997)126<0707:IOTAPO>2.3.CO;2 
Pienaar, U.V., 1978, The freshwater fishes of the Kruger National Park, National Parks Board of Trustees, Pretoria.

Roux, F., 2013, 'A study on the behaviour of tigerfish (Hydrocynus vitattus) using biotelemetry, to determine habitat utilisation and survival strategies in the lower Incomati River system', PhD dissertation, University of Johannesburg, Johannesburg, South Africa, viewed 29 January 2018 from http://hdl.handle.net/10210/12356

Roux, F., Kleynhans, C.J., Thirion, C., Hill, L., Engelbrecht, J.S., Deacon, A.R. et al., 1990 'Adaptive assessment and management of riverine ecosystems; The Crocodile/ Elands River case study', Water SA 25(4), 501-507.

Seaman, D.E. \& Powell, R.A., 1996, 'An evaluation of the accuracy of kernel density estimators for home range analysis', Ecology 77, 2075-2085. https://doi. org/10.2307/2265701

Silwerman, B.W., 1986, Density estimation for statistics and data analysis, Chapman and Hall, London, UK.

Skelton, P.H., 2001, A complete guide to the freshwater fishes of Southern Africa, Struik Publishers, South Africa.

Spedicato, M.S., Lembo, G. \& Marmulla, G. (eds), 2005, Aquatic telemetry: Advances and applications, Food and Agricultural Organisation of the United Nations (FAO) Rome.

SPSS Inc., 2009, PASW Statistics for Windows, version 18.0, SPSS Inc., Chicago, IL.

Steyn, G.J., 1993, 'Physico-chemical characteristics of tigerfish semen', Southern African Journal of Wildlife Research 23, 44-47.
Steyn, G.J., Gagiano, C.L., Deacon, A.R. \& Du Preez, H.H., 1996, 'Notes on the induced reproduction and development of tigerfish, Hydrocynus vittatus (Characidae), embryos and larvae', Environmental Biology of Fishes 47, 387-398. https://doi. org/10.1007/BF00005052

Steyn, G.J. \& Van Vuren, J.H.J., 1991, 'Cryopreservation of the spermatozoa of two African fishes (Characidae)', Southern African Journal of Wildlife Research 21, 76-81.

Thorstad, E.B., Økland, F. \& Heggeberget, T.G., 2001, 'Are long term negative effects from external tags underestimated. Fouling of an externally attached telemetry transmitter', Journal of Fish Biology 59, 1092-1094. https://doi.org/10.1111/ j.1095-8649.2001.tb00174.x

Van Loggerenberg, N.P., 1980, Kunsmatige teelt van die tiervis Hydrocynus vittatus Castelnau, en die biologiese aspekte wat daarmee verband hou, Projek TN $6 / 4 / 2 / 2 / 1 / 18$, Transvaal Provinsiale Vissery Instituut, Lydenburg.

Van Loggerenberg, N.P., 1982, Kunsmatige teelt van die tiervis Hydrocynus vittatus Castelnau, in Transvaal, Vierde projekverslag, Projek TN 6/4/2/2/1/18, Transvaal Provinsiale Vissery Instituut, Lydenburg.

Van Loggerenberg, N.P., 1983, 'Conservation of tigerfish and fish farming techniques', Fauna and Flora 40, 30-31.

Wilber, C.G., 1983, Turbidity in the aquatic environment. An environmental factor in fresh and oceanic waters, CC Thomas, Springfield, Illinois, USA.

Worton, B.J., 1989, 'Kernel methods for estimating the utilisation distribution in home range studies', Ecology 70, 164-168. https://doi.org/10.2307/1938423 